\title{
Reflections on the Mittani Emergence
}

The genesis of the Mittani polity is a research problem of no little difficulty, and the organizers of the Topoi conference deserve credit for attempting to extend the frontiers of our knowledge on the issue. Admittedly, many of the contributions in this volume steer clear of the topic except in a decidedly tangential fashion, but in their state-of-the art presentations on west Asian Bronze Age issues they provide a broad foundation for future work. In this short paper, I offer a few observations and reflections on some of the issues relevant to Mittani's origins.

As is customary, we must be aware of the limitations of our evidence. In this case, those inadequacies are especially daunting, in that there is a scarcity of both textual and archaeological data relevant to the origins of the Mittani state. This is not surprising, since documentation generally tends to be more profuse in periods of state florescence, when central institutions are in full operation, than in the period when a new polity forms. ${ }^{\mathrm{I}}$ We face similar restrictions when considering the emergence of the first states in Uruk Mesopotamia, dynastic Egypt, the Sargonic "empire" of Akkad, and many other cases. Rare exceptions to this rule might include Šamši-Adad's kingdom of upper Mesopotamia in the early second millennium $\mathrm{BC}$, although this is a state that failed to outlast its founder, or the Hittite Old Kingdom (see above Klinger, p. 75-90; Michel, p. III-I36). ${ }^{2}$

Given the scarcity of archaeological and textual data, there are several possible approaches to studying the Mittani emergence. One is to examine the period of Mittani's florescence and then project backwards, searching for clues to its origins in the institutions or records of its later eras, as has been done for the origins of Mesopotamian civilization in the fourth millennium BC. ${ }^{3}$ Another is to consider the period prior to Mittani's emergence and project forward, while a third tack is to examine data from regions outside Mittani for evidence relevant to upper Mesopotamia and Syria at the time of Mittani state formation. The papers in this volume offer evidence and arguments that fall into each of these three categories. At present, they combine to produce a picture that remains frustratingly incomplete, but hints of progress can be discerned.

* The Johns Hopkins University Baltimore.

I Textual evidence is likely to be meager in the period before full-scale bureaucracy has been installed, while archaeologists tend to gravitate toward contexts that produce monumental architecture, which is also less likely to derive from the onset of a new political system.

2 An example from a completely different time and place is that of late I8th century AD Hawai'i, whose emergence as a unified kingdom was observed and recorded by European and American witnesses (and participants); Kirch 2010.

3 Algaze 2008 . 
In addition to the issue of minimal evidence, there are difficulties of dating. West Asian absolute chronology for the early-middle second millennium BC remains problematic, with competing chronological models still battling for acceptance. 4 De Martino (p. 6I-74) has discussed two primary temporal schemes relating to the birth of the Mittani state, one dating the event prior to the collapse of Yamhad and the other assigning it to a period after the withdrawal of the forces of Murshili I, a scenario de Martino prefers. If we consider the two most widely-utilized absolute chronological models, the Middle Chronology, dating the fall of Babylon to I595 BC (or, in the modified Middle Chronology, I580 BC)5 and the ultra-low chronology dating the fall of Babylon to $1499 \mathrm{BC},{ }^{6}$ we arrive at the four following possibilities, bearing in mind that Egyptian sources reveal that Mittani was in existence by at least ca. $1500 \mathrm{BC}$ :

\section{Middle Chronology:}

I. If Mittani appears before the fall of Yamhad, it has a long early history (ca. I700/ I650-I500 BC) with very little documentation.

2. If Mittani's origins begin sometime after Murshili I's withdrawal, there is a "Dark Age" of political fragmentation after the collapse of Yamhad lasting ca. 50-Ioo years (ca. I600/I550-I500 BC).

\section{Ultra-Low Chronology:}

3. If Mittani appears before the fall of Yamhad, it has a relatively brief and meagerly documented early history (ca. I600/I550-I500 BC).

4. If Mittani emerges after Murshili I's withdrawal ca. I500 BC, its genesis would be approximately synchronous with the first Egyptian campaigns against it.

Options I and 4 appear to be the least likely of the four possibilities, but one cannot rule out any of them definitively.

The archaeological evidence also presents chronological problems. There is a recognized distinction between Middle and Late Bronze Age material culture assemblages in Syria and upper Mesopotamia that must date to the mid-second millennium BC, but the transition from MB to LB is a smooth one, and assemblages from the period of late MB to early LB are not necessarily easy to distinguish from one another. Even if later MB and early LB strata were easy to differentiate from each other, it is not at all certain that this break corresponds to the transition from pre-Mittani to Mittani political hegemony.7 Of course, one should not expect political change to be concurrent with shifts in material culture, but with-

4 Schwartz 2008.

5 Michel - Rocher 2000; Michel 2002.

6 Gasche et al. I998.

7 Moreover, the Jazirah was incorporated into the Mittanian polity before western Syria or Cilicia, which means that early LB west of the Euphrates probably includes a pre-Mittani phase. 
out such synchronicity, the assignment of specific strata to the period of Mittani's emergence will be difficult or impossible.

Despite these problems, progress is being made on our understanding of mid-late second millennium material culture sequences in upper Mesopotamia and Syria with the publication of data from Tall al-Rimah, Tall Bderi, Tall Brak, and elsewhere. ${ }^{8}$ Some of the authors of these publications have suggested candidates for diagnostics of the onset of Mittani control. One example is the light-on-dark painted Nuzi Ware.9 Unfortunately, the employment of Nuzi Ware as a diagnostic of Mittani is problematic because the pottery is relatively rare and only fitfully appears in surface survey collections, as opposed to the more abundant Khabur Ware of the preceding period. It is also not clear that the first appearance of Nuzi Ware necessarily coincides with the emergence of Mittani in every case.

Given the contexts Nuzi Ware is found in, these ceramics are interpretable as highquality luxury products associated with the elite of the Mittani empire. ${ }^{\text {Io }}$ It is curious that pottery is once again a marker of high social status after the many centuries when other artifactual media fulfilled that function. Since the political and social institutions found throughout the Mittani realm show considerable variability (see above Dassow, p. II-32 and Otto, p. 33-6o), Nuzi Ware might have functioned as an integrative instrument, a marker of Mittani elite identity tying diverse local authorities to the imperial center. ${ }^{I I}$ The role of this pottery, particularly manifested in the shape of goblets, in contexts of ceremonial or celebratory wine (?)-drinking might reward further consideration. ${ }^{\mathrm{I2}}$

Other ceramic diagnostics associated with the Mittani period include piecrust potstands and red-edged bowls ${ }^{13}$ but, as with Nuzi Ware, it is not clear if their appearance is synchronous with that of Mittani. ${ }^{14}$ Also common throughout the Mittani kingdom are large shallow bowls with simple rounded rims, sometimes so flat as to be characterized as plates. ${ }^{15}$ Whether these appear at the same time as Mittani rule is, again, uncertain.

8 Postgate et al. I997; Pfälzner I995 and 2007; Oates et al. I997.

9 Oates et al. I997, 67; Postgate et al. I997, 54f.; “ ... its origins coincide with the period of Mittani hegemony", Oates et al. I997, 67 .

Io Postgate et al. I997, 54 .

II The core-molded glass objects that also become popular luxury items in the period might be viewed in a similar light.

I2 Bunimovitz - Greenberg 2004; Mazzoni 1994

I3 Postgate et al. I997, 56; Oates et al. I997, 73; “ ... one of the most distinctive Mitanni innovations".

I4 Pfälzner 2007, 240 proposes that Dark on Buff Animal Ornamented Ware is associated particularly with the early Mittani period (in his terminology, Middle Jazirah IA), but it is also found in the pre-Mittani (Middle Bronze) era (Faivre - Nicolle 2007, plate 9. 269. 309; Oates et al. I997, 7If.; Postgate et al. I997, 53).

I5 Akkermans - Schwartz 2003, 332, fig. I0.3a-c; Czichon - Werner 2008, Taf. 83. 88-90. 96-99; Oates et al. I997, I68-I7I, fig. I84. 63-76, fig. I85. 8I-89; Mazzoni 2002, pl. 6o, 33. 35. pl. 6I, 4I-44. 
The popularity of these shallow bowls merits further examination. For example, one might inquire whether the upsurge in their frequency was associated with a change in foodways. A shift from the deeper bowls of the Middle Bronze Age ${ }^{\mathrm{I}} 6$ to the shallow Late Bronze bowls might entail a transition from the prevalence of more liquid foods (e.g. stews, soups) to more solid culinary productions. If the proliferation of shallow bowls indeed marks a change in cuisine, such developments may be coincident with such political and economic circumstances as migration, social rivalry, or social emulation. ${ }^{17}$ The new political and cultural importance of the Hurrians could be relevant, since ethnic groups often have cuisines that materialize the concept of shared ethnic identity. ${ }^{18}$ Perhaps the rise of many Hurrians to social prominence by the beginning of the Late Bronze Age resulted in the emulation of their behaviors, including food preparation, by others. If this idea has any traction, it would have to be demonstrated that Hurrian culinary traditions are inferrable from pottery from the pre-Mittani as well as Mittani periods. ${ }^{\text {I9 }}$

Indeed, a major problem in the study of the Mittani emergence is ethnicity. In contrast to the preceding period when Semitic languages were predominant, Hurrian becomes the norm for personal names and, apparently, for the spoken language in Mittani, even as far southwest as Qatna. ${ }^{20}$ Hurrians seem to be understood as an ethnic group by the Hittites and others who refer to the "king of the Hurri lands" or "king of the Hurri troops". If Hurrian was the language of the Mittani elite, then naming practices and the use of the language itself could have been emulated by the subject population. ${ }^{2 \mathrm{I}}$ It is in any case doubtful, as von Dassow explains, that the Hurrianization of the Mittani zone involved a mass migration of Hurrian speakers from the highlands to the lowlands.

A more general question is why Bronze and Iron Age Syro-Mesopotamia was prone to repeated ethnic changeovers, from Amorite to Hurrian to Aramaean. Why did certain ethnic groups and languages enjoy prominence and power and then recede from view, and why does ethnicity come into play in certain periods and places and not others (cf., for instance, the paucity of ethnic references in third-millennium Syro-Mesopotamian texts)? One might propose that ethnicity is significant in cases when non-state populations come

I6 E.g. Nigro 2002, pls. 46. 48.52. 54 .

I7 Mintz - Du Bois 2002.

I8 Emberling I997; Macheachern I998. Present-day ethnography has noted that migrants not only bring in new culinary styles but influence their neighbors' cooking as well, Lockwood - Lockwood 2000.

I9 It must also be conceded that the distinction between Middle and Late Bronze bowls discussed here is not completely sharp - there are shallow bowls in the Middle Bronze assemblages and deeper bowls in the Late Bronze.

20 Richter 2005. As Biga (p. 93-IIO) notes, the use of Hurrian is not apparent in Syria or northern Mesopotamia until the Akkadian period. In the Middle Bronze Age, Hurrian language and onomastica become increasingly evident and finally predominate in the Mittani period. Of course, the "Hurrianization" of Syro-Mesopotamia was not total, even in the Late Bronze period. One can observe substantial Semitic onomastica in Late Bronze texts from middle Euphrates sites such as Munbaqa and Terqa; Mayer 200I; Podany 2002.

2I Note that the same process did not take place in southern Mesopotamia, which was controlled by a Kassite dynasty but showed no signs of linguistic or onomastic "Kassitization". 
into contact (and conflict) with state organizations, or when non-state populations come into conflict with one another. ${ }^{22}$

Since the focus of the Topoi project is "space", it is appropriate that papers in the volume examine Mittani as a spatial and geographical phenomenon (e.g. Koliński, Lyonnet, Otto). ${ }^{23}$ Previous assessments of survey data from the Middle to Late Bronze Age in the Mittani region have emphasized a steady decline in the number of sedentary sites from the Middle to Late Bronze periods, or a move from tells to low, dispersed sites. ${ }^{24}$ Such a pattern of declining sedentism is observable from the southern Levant ${ }^{25}$ to Babylonia. ${ }^{26}$ The increasing aridification of the second millennium may be relevant, but undoubtedly other variables must be taken into consideration. In his detailed synthesis, Koliński (see p. I79-2I2) reveals that this picture of sedentary decline is not uniform, with some subregions evincing an upsurge in sedentary habitation at the same time that others see a sedentary reduction.

With the decline of tells, the cultural landscape changed, with high, conspicuously visible communities replaced by lower, more temporary sites. In this new visual reality, the many tells of the Mittani landscape would be ghostly reminders of a former way of life, in contrast to the new unobtrusive communities. The psychological and cultural effects of such a landscape change would be important to investigate.

Not only are nucleated tells on the decline, but the Mittani period sees a major shift in urban sites in the Jazirah, the Mittani heartland. In this region, urban centers that had dominated political and economic life for many centuries were nearly if not totally abandoned by the end of the Middle Bronze Age - e.g.Tuttul (Tall Bi'a), Šehnā/Šubat-Enlil (Tall Leilan), and Mari (Tall Hariri). New urban and political centers took their place in the Mittani period, such as Tall Fakhariya (Waššukani?) and Tall Hamidiya (Taidu?). It will be important to determine when, how, and why these new urban centers were developed, and the role of the Mittani central authorities in instigating the process.

If there is a diminution of sedentism, are we to assume an uptick in the number of people practicing a lifestyle of mobile pastoralism? Meijer, Lyonnet, and Guichard (this volume) discuss the importance of nomadic pastoralism in the period of the Mari texts, with the king of Mari himself identified as a member of a group that included a large nomadic component. But the Amorite kingdoms with pastoralist connections like those of ZimrīLîm and Šamšĩ-Adad collapsed by the late i8th century, perhaps the result of the inherent weaknesses of "tribal" states. ${ }^{27}$ In the Mittani period, despite the apparent decline in seden-

22 Emberling I997; Levy 2009, I55f.

23 Chambon's (see above, p. 247-255) interesting exercise in "metric cartography" in the Middle Bronze Age provides another approach to the examination of place.

24 Wilkinson 2003; Ur et al. 20II.

25 Gonen I984; Bunimovitz I995.

26 Adams i98I.

27 Ristvet 2012. 
tism, nomadic pastoralists are much less visible in the textual record, and the Mittani state has no obvious pastoralist element. Groups such as the Ahlamu may have been the successors to the Simalites and Yaminites of the Mari texts, but they seem to play a much smaller role in the functioning and concerns of the Mittani state, as far as one can discern. Hurrians from polities in the Zagros or Taurus highlands may have been active participants in the formation of Mittani (see below), but there is no evidence yet to support the involvement of highland pastoralist groups. The relative inconspicuousness of pastoral nomads in the Mittani kingdom is particularly striking given the recurrence of elites with nomadic pastoralist connections in the Iron Age, when Aramaeans dominated an array of polities in the Jazirah and the west.

As Meijer notes (see above, p. I63-I78), the conceptualization of "nomads" as people totally separate from sedentists is probably misleading, since many pastoralists were likely to be attached to sedentary villages and led their flocks out to graze for some months only to return to the village later in the year. ${ }^{28}$ Meijer's suggestion of the dichotomy town/country to replace nomad/sedentary has its own problems, however, since there is unlikely to be a clear distinction between the latter two types. ${ }^{29}$ But even conceding the frequent integration of pastoralist and agriculturalist, one must still acknowledge the existence of large groups of "tribal" pastoralists conducting a mobile lifestyle, as detailed in the Mari texts. ${ }^{\circ}$ Presumably the Ahlamu of the Late Bronze Age are comparable entities.

Broadening our spatial perspective, it will be important to consider the role that people from neighboring regions might have played in the formation of the Mittani polity. ${ }^{3 \text { I }}$ Since the major political entities of Late Bronze Age West Asia - Kassite Babylonia, Old Kingdom Hatti, and Mittani - emerged at roughly the same time, after a period of confusion and paucity of written documentation, their interrelationships during state formation would be important to examine. ${ }^{32}$ Actions emanating from polity to polity were likely to be recursive.

To the south, Babylonia was a traditional source of cultural and ideological models and technologies, as can be seen in the Middle Bronze Age when the Amorite rulers of SyroMesopotamia (and also the Hurrian Turukkeans - see in this volume Eidem, p. I37-I46) emulated southern Mesopotamian architectural and glyptic styles, scribal practices, and royal ideologies. Such emulation seems to taper off in the later Middle Bronze Age, and the

28 See also Porter 20II. On the fluidity of nomad-sedentary lifestyles, see, however, Alizadeh's 2009, I3I cautionary remarks on the difficulties of switching from farming to nomadic pastoralism.

29 See the recent trend among archaeologists to eschew bipolar typologies like male/female, body/mind, subject/object altogether, Meskell 2005. But one should take care not to go too far in rejecting all typology, since science is based on classification, as is, indeed, human thought - words themselves are "types" representing classes of entities.

30 Ristvet 20 I2 notes tellingly that there is no textual evidence for such groups in the third millennium, arguing that they only came into existence in the early second millennium BC.

3 I Stein 2002 .

32 For example, Forlanini 2009, 57 proposes that both Mittani and Kassite Babylonia emerged from the unification of mercenary groups. 
role of southern Mesopotamia as a model to be utilized in the legitimization of Mittani rule seems relatively muted. While writing in Akkadian cuneiform remains the convention for scribal bureaucracy, this practice is likely to have been inherited from the preceding upper Mesopotamian polities rather than directly copied from southern Mesopotamia. Likewise, southern Mesopotamian elements in Mittani glyptic largely seem to have been inherited from Old Babylonian seals. 33

In the northwest, Mittani faced the newly formed Hittite polity. The belligerence of the early Old Hittite rulers towards their neighbors in the southeast must have had significant political and social effects. As Eidem (citing von Dassow) notes, it is likely that the threat posed by the Hittite forces of Hattushili I and Murshili I against the various Hurrian-dominated polities of upper Mesopotamia helped to precipitate the unification of those polities into a single entity.

Economic interconnections with neighboring regions will also be significant, as Biga (this volume, p. 93-IIO) illuminates for the third millennium. The role of long-distance exchange, the acquisition of exotic preciosities by an emerging Mittani elite, 34 and other economic variables are important concerns that studies of Mittani origins should consider. Intra-regional aspects of the economy such as subsistence production or craft manufacture, largely overlooked by the contributors to this volume, are also important (but see in this volume p. 33-6o Otto's comments on craft production in domestic contexts). The consideration of ecofactual data, at present only minimally available, 35 will be an important addition to our discussion when accessible in greater profusion. At Umm el-Marra in the Jabbul plain of western Syria, for example, a specialized focus on onager-hunting in the Middle Bronze period was replaced by a more diversified, localized animal economy in the Late Bronze period. ${ }^{36}$ It will be necessary to determine how this shift in animal exploitation was or was not related to larger events in the rise of Mittani.37

The paucity of attention to issues of subsistence and daily life in this volume (exceptions are provided by Otto and von Dassow) is undoubtedly connected to our discipline's characteristic focus on the elite. But the non-elite, the peasant, the slave, all played major roles in the societies in question and need to be integrated into our discussion.

Moving from issues of space, we may consider temporal variables. Of potential importance is social memory and its uses in the creation of the Mittani state..$^{8}$ Ideas, ideologies, and institutions may have been borrowed from previous polities in order to set the foun-

33 Matthews I990, $47 \mathrm{f}$.

34 Compare the gift-exchange conducted by the later third millennium polities discussed by Biga (see above, p. 93-IIO), or the similar activities undertaken by the Near Eastern rulers in the Amarna period.

35 E.g. van Zeist I994; Riehl 2009; Smith - Munro 2009.

36 Weber in Schwartz et al. 2000; for other comments on the ecofactual data see Miller in Schwartz et al. 2000 and Schwartz - Miller 2007.

37 Adam Maskevich, Johns Hopkins University, is preparing a Ph.D. dissertation on the Mittani period occupation at Umm el-Marra.

38 van Dyke - Alcock 2003; Mills - Walker 2008; Connerton I989. 
dations for Mittani rule. 39 By the I4th century BC at least, it is clear that reference to the Mittani royal past was important, given the employment of "dynastic seals", whereby the reigning Mittani king used the seal of a predecessor in his own administrative transactions, legitimizing his authority through emphasis of his royal lineage. $4^{\circ}$ Although, as von Dassow observes, there are no tales of the kingdom's founders preserved in Mittani documents, de Martino notes that the name of the kingdom, etymologized as "land of Maitta", may refer to an eponymous founder.

Relevant to the question of memory is the vexatious Indo-Iranian (or Indo-Aryan) connection. It appears that the Mittani kings adopted throne names in an Indo-Iranian language, even though they spoke Hurrian. Von Dassow is no doubt correct that the emergence of Mittani did not entail the influx of a large population of Indo-Iranian-speaking immigrants from the east, but the fact that the Mittani kings consistently used Indo-Iranian throne names still requires explanation. Likewise, the mention of Vedic gods in the Shattiwaza treaty and the possible derivation of the designation for the Mittani elite class (maryanni) from an Indo-Iranian word cannot easily be dismissed. ${ }^{\mathrm{I}}$ The power of memory in the IndoIranian case is particularly striking in that Indo-Iranian concepts and terminologies remained potent late in Mittani history, as demonstrated by the later I4th century BC date of the Shattiwaza treaty. If the Mittani elite had its origins in the Hurrian polities of western Iran, a possibility Eidem advances, this might help in understanding the problem: some Indo-Iranian speaking individuals or groups moving through or into Iran may have played important roles in western Iranian Hurrian territories. New archaeological information from central Asia, where groups speaking Indo-European languages and employing the horse and chariot were residing in the second millennium BC, should prove of use as this question is pursued. Anthony ${ }^{42}$ suggests that Mittani was "founded by Old Indic-speaking mercenaries, perhaps charioteers ...” and speculates that they originated in the Indo-European-speaking chariot-riding Andronovo/Tazabagyab cultures of Bactria and Margiana.43

Although von Dassow insists that Mittani success must be attributed to other factors, the role of the horse and chariot is another piece of the Mittani puzzle that deserves more attention. The importance of chariotry in Mittani is well-demonstrated by its clear affiliation with the maryanni elite class, while Mittani equestrian capabilities are well-documented in the Kikkuli horse-training text. The connection to Central Asian chariot riders posited by Anthony is, at present, tenuous, but should not be peremptorily rejected.

39 Bronson 2006. For example, Eidem (see above, p. I37-I46) floats the idea that the Mittani rulers emulated Shamshi-Adad by establishing their capital in the Upper Khabur, a strategic intermediary region. One must acknowledge, however, the significant time gap between the two sets of monarchs.

40 Auerbach I99I.

4 I Kuhrt I995, 297.

42 Anthony 2007, 50. 454.

43 Forlanini 2009, 57 also proposes that Hurrian mercenary groups coalesced under the leadership of a clan of Indo-Iranian origin. 

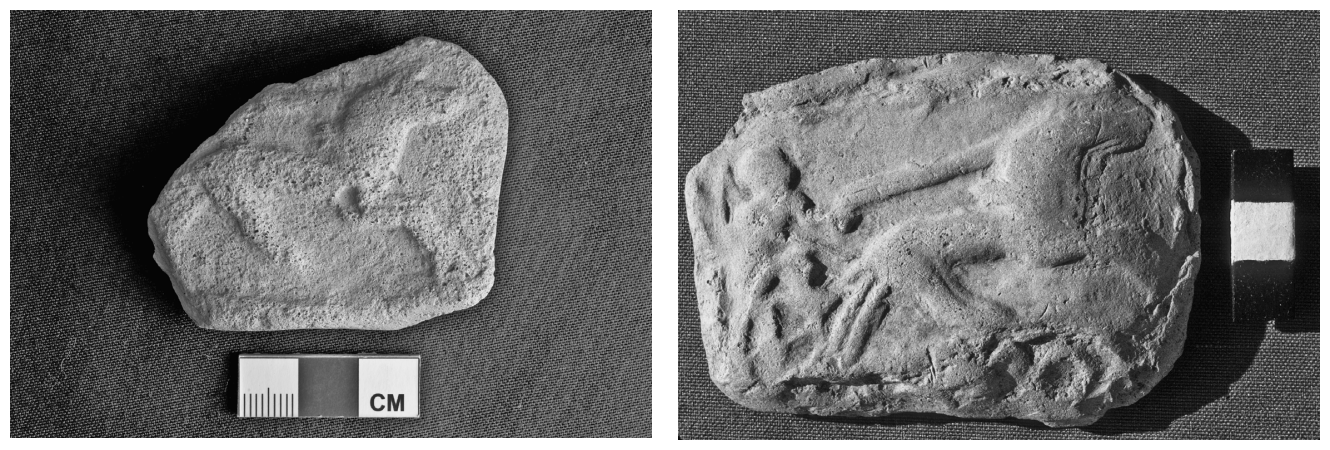

Figure 1 | Terracotta plaques from Umm el-Marra: (left) fragmentary plaque with team of horses preserved; (right) charioteer with a bow and a team of horses.

Despite the importance of chariotry in Mittani, images of chariots are relatively uncommon in Mittani representational art, indicating that the Mittani elite employed other symbols to demonstrate their authority and legitimacy. 44 Nevertheless, an addition to the small corpus of such representations has been provided by the excavations at Umm el-Marra, where two examples of Mittani period terracotta plaques depicting horse-drawn chariots have been recovered (Fig. I). 45

Given the current state of our evidence, we will continue to find the issue of Mittani origins difficult to understand and explicate. But it is a problem likely to continue to attract interest, as problems of origins tend to do, and we have reason to hope that the results from continued excavations at sites like Fakhariya, Hamidiya, and Brak as well as sites not yet tested - even, perhaps in Iraq - will be of assistance.

\title{
Bibliography
}

\author{
Adams 198I \\ R. McC. Adams, Heartland of Cities (Chicago I98I).
}

\section{Akkermans - Schwartz 2003}

P. M.M.G. Akkermans - G. M. Schwartz, The Archaeology of Syria: From Complex HunterGatherers to Early Urban Societies (ca. I6,000-300 B.C.) (Cambridge 2003).

\section{Algaze 2008}

G. Algaze, Ancient Mesopotamia at the Dawn of Civilization (Chicago 2008).

44 Feldman - Sauvage 2010.

45 For the complete example, found in the Acropolis North in I999, see discussion in Schwartz et al. 2003, 35I-353. The fragmentary specimen was found in 2008 below the mound surface in the Acropolis Northwest trench I226/3906 together with other Late Bronze artifactual materials such as pottery and a terracotta zebu figurine. 


\section{Alizadeh 2009}

A. Alizadeh, Prehistoric Mobile Pastoralists in South-central and Southwestern Iran, in: J. Szuchman (ed.), Nomads, Tribes, and the State in the Ancient Near East, Oriental Institute Seminars 5 (Chicago 2009) I29-I46.

\section{Anthony 2007}

D. W. Anthony, The Horse, the Wheel, and Language (Princeton 2007).

\section{Auerbach I99I}

E. Auerbach, Heirloom Seals and Political Legitimacy in Late Bronze Age Syria, Akkadica 74-75, I99I, I9-36.

\section{Bronson 2006}

B. Bronson, Patterns of Political Regeneration in Southeast and East Asia, in: G. Schwartz J. Nichols (eds.), After Collapse: The Regeneration of Complex Societies, (Tucson 2006) I37-I43.

\section{Bunimovitz 1995}

S. Bunimovitz, On the Edge of Empires - Late Bronze Age (I500-I200 BCE), in: T. Levy (ed.), The Archaeology of Society in the Holy Land (New York I995) 320-33I.

\section{Bunimovitz - Greenberg 2004}

S. Bunimovitz - R. Greenberg, Revealed in their Cups: Syrian Drinking Customs in Intermediate Bronze Age Canaan, BASOR 334, 2004, I9-3I.

\section{Connerton 1989}

P. Connerton, How Societies Remember (Cambridge I989).

\section{Czichon - Werner 2008}

R. Czichon - P. Werner, Die bronzezeitliche Keramik. Ausgrabungen in Tall Munbaqa-Ekalte IV, WVDOG II8 (Wiesbaden 2008).

van Dyke - Alcock 2003

R. van Dyke - S. Alcock (eds.), Archaeologies of Memory (Malden 2003).

\section{Emberling 1997}

G. Emberling, Ethnicity in Complex Societies: Archaeological Perspectives, JAR 5, I997, 295-344.

\section{Faivre - Nicolle 2007}

X. Faivre - Ch. Nicolle, La Jézireh au Bronze moyen et la céramique du Khabur, in: M. alMaqdissi - V. Matoïan - C. Nicolle (eds.), Céramique de l'âge du bronze en Syrie II: L'Euphrate et la région de Jézireh (Beirut 2007) I79-229.

\section{Feldman - Sauvage 2010}

M. H. Feldman - C. Sauvage, Objects of Prestige? Chariots in the Late Bronze Age Eastern Mediterranean and Near East, Ägypten und Levante 20, 20I0, 67-I82.

\section{Forlanini 2009}

M. Forlanini, Upper Mesopotamia in the Middle of the I7th Century BC According to the Hittite Texts, Kaskal 6, 2009, 49-75. 


\section{Gasche et al. 1998}

H. Gasche - J. Armstrong - S. W. Cole - V. G. Gurzadyan, Dating the Fall of Babylon: A Reappraisal of Second-Millennium Chronology (Ghent I998).

\section{Gonen 1984}

R. Gonen, Urban Canaan in the Late Bronze Period, BASOR 253, I984, 6I-73.

Kirch 2010

P. Kirch, How Chiefs Became Kings: Divine Kingship and the Rise of Archaic States in Ancient Hawai'i (Berkeley 20I0).

\section{Kuhrt 1995}

A. Kuhrt, The Ancient Near East: ca. 3000-330 BC (London I995).

\section{Levy 2009}

T. E. Levy, Pastoral Nomadism and Iron Age Metal Production in Ancient Edom, in: J. Szuchman (ed.), Nomads, Tribes and the State in the Ancient Near East: Cross-Disciplinary Perspectives, Oriental Institute Seminars 5 (Chicago 2009) I47-I77.

\section{Lockwood - Lockwood 2002}

W. G. Lockwood - Y. R. Lockwood, Continuity and Adaptation in Arab American Foodways, in: N. Abraham - A. Shryock (eds.), Milk: Beyond Dairy (Detroit 2002) 515-559.

\section{Macheachern 1998}

S. Macheachern, Scale, Style, and Cultural Variation: Technological Traditions in the Northern Mandara Mountains, in: M. Stark (ed.), The Archaeology of Social Boundaries (Washington D.C. I998) I07-I3I.

\section{Matthews 1990}

D. M. Matthews, Principles of Composition in Near Eastern Glyptic of the Later Second Millennium BC (Freiburg I990).

\section{Mayer 200I}

W. Mayer, Tall Munbaqa-Ekalte II: die Texte (Saarbrücken 200I).

\section{Mazzoni 1994}

S. Mazzoni, Drinking Vessels in Syria: Ebla and the Early Bronze Age, in: L. Milano (ed.), Drinking in Ancient Societies: History and Culture of Drinks in the Ancient Near East (Padova 1994) 245-276.

\section{Mazzoni 2002}

S. Mazzoni, The Late Bronze Age Pottery Production in Northwestern Central Syria, in: M. alMaqdissi - V. Matoïan - C. Nicolle (eds.), Céramique de l'âge du bronze en Syrie I: La Syrie du sud et la vallée de l'Oronte (Beirut 2002) I29-I42.

\section{Meskell 2005}

L. Meskell, Introduction: Object Orientations, in: L. Meskell (ed.), Archaeologies of Materiality (Malden 2005) I-I7.

\section{Michel 2002}

C. Michel, Nouvelles données pour la chronologie du Ile millénaire, Nouvelles assyriologiques brèves et utilitaires I, 2002,I7f., no. 20. 
Michel - Rocher 2000

C. Michel - P. Rocher, La chronologie du IIe millénaire revue à l'ombre d'une éclipse du soleil, JEOL 35-36, 2000, III-I26.

Mills - Walker 2008

B. Mills - W. Walker (eds.), Memory Work: Archaeologies of Material Practices (Santa Fe 2008).

Mintz - Du Bois 2002

S. W. Mintz - Ch. M. du Bois, The Anthropology of Food and Eating, Annual Review of Anthropology 3I, 2002, 99-II9.

\section{Nigro 2002}

L. Nigro, The Middle Bronze Age Pottery Horizon of Northern Inner Syria on the Basis of the Stratified Assemblages of Tell Mardikh and Hama, in: M. al-Maqdissi - V. Matoïan - C. Nicolle (eds.), Céramique de l'âge du bronze en Syrie I: La Syrie du sud et la vallée de l'Oronte (Beirut 2002) 97-I28.

Oates et al. 1997

D. Oates - J. Oates - H. McDonald, Excavations at Tell Brak. Volume I: The Mitanni and Old Babylonian Periods (London 1997).

\section{Pfälzner 1995}

P. Pfälzner, Mittanische und Mittelassyrische Keramik. Eine chronologische, funktionale und produktionsökonomische Analyse (Berlin 1995).

\section{Pfälzner 2007}

P. Pfälzner, The Late Bronze Age Ceramic Traditions of the Syrian Jazirah, in: M. alMaqdissi - V. Matoïan - C. Nicolle (eds.), Céramique de l'âge du bronze en Syrie II: L'Euphrate et la région de Jézireh (Beirut 2007) 23I-299.

\section{Podany 2002}

A. Podany, The Land of Hana: Kings, Chronology and Scribal Tradition (Bethesda 2002).

\section{Porter 20II}

A. Porter, Mobile Pastoralism and the Formation of Near Eastern Civilizations:Weaving Together Society (Cambridge 20II).

Postgate et al. 1997

C. Postgate - D. Oates - J. Oates, The Excavations at Tell al Rimah: The Pottery (Warminster I997).

\section{Richter 2005}

T. Richter, Qatna in the Late Bronze Age, in: D. Owen - G. Wilhelm (eds.), Studies on the Civilization and Culture of Nuzi and the Hurrians vol. I5, General Studies and Excavations at Nuzi II/I (Bethesda 2005) I09-I26.

\section{Riehl 2009}

S. Riehl, Archaeobotanical Evidence for the Interrelationship of Agricultural Decision-Making and Climate Change in the Ancient Near East, Quaternary International I97, 2009, 93-II4. 


\section{Ristvet 2012}

L. Ristvet, Resettling Apum: Tribalism and Tribal States in the Tell Leilan Region, Syria, in: N. Laneri - P. Pfälzner - S. Valentini (eds.), Looking North: The Socio-Economic Dynamics of Northern Mesopotamian and Anatolian Regions during the Late Third and Early Second Millennium B.C. (Tübingen 20I2) 37-50.

\section{Schwartz 2008}

G. M. Schwartz, Problems of Chronology: Mesopotamia, Anatolia, and the Syro-Levantine Region, in: J. Aruz - K. Benzel - J. Evans (eds.), Beyond Babylon: Art, Trade and Diplomacy in the Second Millennium B.C. (New York 2008) 450-452.

\section{Schwartz et al. 2000}

G. M. Schwartz - H. H. Curvers - F. Gerritsen - J. MacCormack - N. F. Miller - J. A. Weber, Excavation and Survey in the Jabbul Plain: The Umm el-Marra Project I996-I997, AJA I04, 2000, 419-462.

\section{Schwartz - Miller 2007}

G. M. Schwartz - N. F. Miller, The "Crisis" of the Late Third Millennium B.C.: Ecofactual and Artifactual Evidence from Umm el-Marra and the Jabbul Plain, in: C. Kuzucuoğlu - C. Marro (eds.), Sociétés humaines et changement climatique à la fin du troisième millénaire: une crise a-t-elle eu lieu en Haute Mésopotamie?, Varia Anatolica I9 (Paris 2007) I79-204.

\section{Smith - Munro 2009}

A. Smith - N. D. Munro, A Holistic Approach to Examining Ancient Agriculture, Current Anthropology 50/6, 2009, 925-936.

\section{Stein 2002}

G. J. Stein, From Passive Periphery to Active Agents: Emerging Perspectives in the Archaeology of Interregional Interaction, American Anthropologist 104, 2002, 903-9I6.

Ur et al. 20II

J. Ur - P. Karsgaard - J. Oates, The Spatial Dimensions of Early Mesopotamian Urbanism: The Tell Brak Suburban Survey, 2003-2006, Iraq 73, 20II, I-I9.

\section{van Zeist 1994}

W. van Zeist, Some Notes on Second Millennium B.C. Plant Cultivation in the Syrian Jazira, in: H. Gasche - M. Tanret-C. Janssen - A. Degraeve (eds.), Cinquante-deux Reflexions sur le Proche-Orient Ancien (Leuven I994) 54I-553.

Wilkinson 2003

T. J. Wilkinson, Archaeological Landscapes of the Near East (Tucson 2003). 
